\title{
マイクロチップレーザー励起によるポータブル波長可変テラヘルツ光源
}

\author{
林伸一郎 ${ }^{1,2}$, 渋谷 孝幸 ${ }^{1,3}$, 酒井博 ${ }^{4}$, 安井孝成 ${ }^{5}$, 平等 拓範 ${ }^{6}$, 小川 雄一 ${ }^{2}$, 大谷知行 ${ }^{1}$, 川瀬 晃道 ${ }^{1,2,3}$ \\ '理化学研究所 ( $9980-0845$ 宮城県仙台市青葉区荒巻字青葉519-1399) \\ ${ }^{2}$ 東北大学 (广981-8555 宮城県仙台市青葉区堤通雨宮町1-1) \\ ${ }^{3}$ 名古屋大学 ( \\ 4浜松ホトニクス ( $4344-8601$ 静岡県浜松市浜北区平口5000) \\ ${ }^{5}$ 長岡科学技術大学 ( $9940-2188$ 新潟県長岡市上富岡町1603-1) \\ 6分子科学研究所（广444-8585 愛知県岡崎市明大寺町字西郷中 38$)$
}

\section{Portable and Tunable Terahertz-Wave Parametric Generator Pumped by Microchip Nd:YAG Laser}

\author{
Shin ichiro HAYASHI, ${ }^{1,2}$ Takayuki SHIBUYA,${ }^{1,3}$ Hiroshi SAKAI,${ }^{4}$ Takanari YASUI, ${ }^{5}$ \\ Takunori TAIRA,${ }^{6}$ Yuichi OGAWA, ${ }^{2}$ Chiko OTANI, ${ }^{1}$ and Kodo KAWASE ${ }^{1,2,3}$ \\ ${ }^{1}$ RIKEN, 519-1399 Aramakiaoba, Aoba, Sendai, Miyagi 980-0845 \\ ${ }^{2}$ Tohoku University, 1-1 Tsutsumidori Amamiyamachi, Aoba, Sendai, Miyagi 981-8555 \\ ${ }^{3}$ Nagoya University, Furo-cho, Chikusa, Nagoya, Aichi, 464-8603 \\ ${ }^{4}$ Hamamatsu Photonics K. K., 5000 Hiraguchi, Hamakita, Hamamatsu, Shizuoka 434-8601 \\ ${ }^{5}$ Nagaoka University of Technology, 1603-1 Kamitomiokacho, Nagaoka, Niigata 940-2188 \\ ${ }^{6}$ Institute for Molecular Science, 38 Nishigo-Naka, Myodaiji, Okazaki, Aichi 444-8585
}

(Received December 4, 2008)

\begin{abstract}
We have developed a terahertz wave parametric source using $\mathrm{MgO}: \mathrm{LiNbO}_{3}$ pumped by a subnanosecond, passively Q-switched, microchip Nd:YAG laser. This pump source allows high intensity pumping without damaging of the nonlinear crystal and generates a narrow linewidth and tunable terahertz wave with injection seeding by an external cavity diode laser for the idler wave. The high intensity pumping causes a gain curve broadening of the terahertz wave parametric generation, especially in the high frequency region. We obtained an output terahertz wave with a tuning range of $0.9-3 \mathrm{THz}$ $(100-330 \mu \mathrm{m})$, a peak power of $100 \mathrm{~mW}$, and a linewidth of less than $10 \mathrm{GHz}$. This room temperature operated, palm-sized source promises to be a new widely tunable terahertz wave source that is suited to a variety of applications.
\end{abstract}

Key Words: Terahertz wave, Far-infrared lasers, Frequency conversion, Parametric amplifiers

\section{1.はじめに}

近年，遠赤外線あるいはサブミリ波の領域において新 しい発生・検出方式の研究が急速に進展しつつあり, そ れに伴ってテラヘルツ光という言葉がよく用いられるよ うになった。テラヘルツ光とは，マイクロ波と赤外光の 間に位置する電磁波であり, $10^{12} \mathrm{~Hz}(1 \mathrm{THz})$ 付近の周波 数を持つことからこう呼ばれている. テラヘルツ光の厳 密な定義はまた存在しないが，およそ波長が1 mm〜 $30 \mu \mathrm{m}$ の領域，周波数に換算すると $0.3 \mathrm{THz} \sim 10 \mathrm{THz}$ の領 域を指す.

テラヘルッ光は電波のように紙, プラスチック，ビ ニール, 繊維, 半導体, セラミクス, 脂肪, 粉体, 水な ど様々な物質を透過すると共に, 光波のようにレンズゃ ミラーで空間を自在に取り回すことができる，また，電 波に比べて波長が短いため, 多くのイメージング用途に
とって必要十分な波長程度の空間分解能を有している. さらに近年, ビタミンや糖, 医薬品, 農薬, 禁止薬物, 爆薬など様々な試薬類に固有の吸収スペクトル（指紋ス ペクトル)が3 THz以下の低周波数領域で見出され，そ の分光応用可能性が広がりつつある。また, これまでこ の領域の光源・検出器が未発達のために解明されていな い物理現象・生命現象・物質構造の解明，および宇宙， 大気や生体，プラズマなどの計測・診断，さらにはテラ ヘルツ光による非線形現象など幅広い基礎的研究分野の 発展につながる可能性も大きいばかりでなく，この周波 数帯の電磁波の特徵を生かしたイメージング, 非破壊計 測, 爆薬・禁止薬物検出，バイオテクノロジーや医学へ の応用，および様々な産業応用への可能性など，テラへ ルツ光研究は今後ますます重要になることが予想される1).

しかしながら，この領域は，光波と電波のそれぞれの 領域が重要な応用技術とともに発展・成熟してきたのと 
は対照的に，発生および検出技術面および応用面共に開 拓が遅れているが, 近年, レーザー光の波長変換を用い て比較的簡便にテラヘルツ光発生が実現できるように なってきた. 最も一般的なテラヘルツ光の発生・検出方 法は, 電気光学結晶や光伝導性アンテナ, 半導体, 超伝 導体等をフェムト秒レーザーで励起して広帯域なテラへ ルツ光パルスを発生・検出するテラヘルツ時間領域分光 法 (THz Time Domain Spectroscopy $)^{2-5)}$ である。このTHzTDSは, 従来の熱型光源を用いた遠赤外フーリエ変換分 光光度計に比べて非常に感度が高く，物質のテラヘルツ 分光やイメージング等に応用され成果を上げている.

一方で, 物質の特定量子状態への励起, 超高分解能の 分光，超高速光エレクトロニクス等への応用にはスペク トル線幅の狭い周波数可変テラヘルツ光源が必要であ る. 現在, 周波数 $1 \mathrm{THz}$ 程度以下の領域では, 比較的コ ンパクトで発振スペクトル幅の狭い周波数可変な光源で ある後進波管(Backward Wave Oscillator) が利用できる が, 寿命が数百時間程度と短く, BWOの出力が急減す る $1 \mathrm{THz}$ 以上の高周波領域での光源開発は遅れている. この領域における広帯域周波数可変テラヘルツ光源に

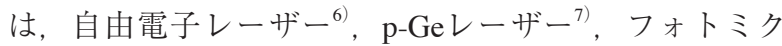
サー ${ }^{8)}$ などがあるが，それぞれシステムが大規模であ る, 極低温を要する, 出力が低いなどの課題を抱えてい る. また, 中赤外域で高出力を実現している量子カス ケードレーザー ${ }^{9)}$, 原理的に波長可変性に乏しく, $3 \mathrm{THz}$ 以下の領域では, 数例の報告例はあるものの現在 はレーザー発振が困難である。このため, 可搬性にも通 じるコンパクトで室温動作可能かつ簡便なテラヘルッ光 源が実現すれば，この領域の研究が飛躍的に進展するの は間違いない.

このような背景の下, 我々は非線形光学効果 (二オブ酸 リチウム $\left(\mathrm{LiNbO}_{3}\right)$ 結晶中の誘導ポラリトン散乱現象 $\left.{ }^{10,11}\right)$ を用いたパラメトリック波長変換によるテラヘルッ光源 (テラヘルツ光パラメトリック発生器：Terahertz-wave Parametric Generator，およびテラヘルッ光パラメトリッ ク発振器 : TP Oscillator, 光注入型テラヘルツ光パラメ トリック発生器 : injection-seeded TPG)の研究に取り組 んでいる ${ }^{12)}$. 本光源は非線形光学結晶と励起光源だけで テラヘルツ光を発生させるため, 小型簡便かつ室温動作 可能であり, $\mathrm{LiNbO}_{3}$ 結晶のパラメトリック利得の広带 域性から, 周波数領域も $1 \mathrm{THz}$ 以下から $3 \mathrm{THz}$ 以上と広 い. 従来, テラヘルッ光パラメトリック光源の小型化を 制限していた要因のひとつに, 励起光源が挙げられる. テラヘルツ光の波長制御のため, 共振器によってアイド ラー光を選択するためには, パルス幅の長い励起光が必 要であるため, 励起光源のサイズが大きくなってしま う。共振器を用いないパラメトリック発生の場合, パル ス幅の制約なくコンパクトな短パルス励起光源を用いる ことができる。このとき, 発生するテラヘルッ光は励起 光源の性質に依存する。高出力化, 広帯域化を目指す場 合にはトップハット型の強度分布を持つマルチモード励 起光源を ${ }^{13)}$, 種光注入による線幅の狭窄化を目指す場合 には線幅の狭いシングルモード発振の励起光源を用いれ
ばよい，本報告では，ポータブル波長可変光源を目指 し，励起光源としてマイクロチップレーザーを用いた光 注入型テラヘルツ光パラメトリック光源について述べ る.

\section{2. 波長可変テラヘルツ光発生の原理}

Qスイッチ動作のパルスレーザーから発生したレー ザー光のような強電場を持つ電磁波が横光学フォノン モードをもつ非線形光学結晶を通過すると, 光子と格子 振動が結合してポラリトンと呼ばれる素励起状態を形成 する. Fig. 1に, 非線形光学結晶として $\mathrm{LiNbO}_{3}$ を利用し た場合のポラリトンの分散曲線を示す。共鳴周波数 $\omega_{0}$ 付 近では格子様に振舞うが，共鳴周波数から十分離れた低 周波数領域では光子様に振舞う。このため, ポラリトン を介した誘導ラマン散乱(誘導ポラリトン散乱)によっ て, 広帯域なテラヘルツ光発生を行うことができる。誘 導ポラリトン散乱は, $\mathrm{LiNbO}_{3} や \mathrm{LiTaO}_{3}, \mathrm{GaP}$ な゙の極性 結晶で観測されることが報告されている特。 は, 可視〜近赤外領域で広帯域に透明 (0.4-5.5 $\mu \mathrm{m})$ で光 損傷に対する耐性が高く(損傷限界>数百 $\left.\mathrm{MW} / \mathrm{cm}^{2}\right)^{15)}$, 誘導散乱で高い利得が得られ，テラヘルツ光の結晶中の ロスが他の材料に比べて小さい ${ }^{16)}$ ，などの特性をもつこ とから高出力, 広帯域なテラヘルツ光発生に有利であ る.

誘導ポラリトン散乱過程では, 励起光 (周波数 $\omega_{p}$ ) とア イドラー光 $\left(\omega_{i}\right)$, ポラリトン $\left(\right.$ テラヘルツ光 $\left.; \omega_{T}\right)$ の間 に, エネルギー保存則 $\omega_{p}=\omega_{i}+\omega_{T}$ と運動量保存則 (ノン コリニア位相整合条件) $\boldsymbol{k}_{p}=\boldsymbol{k}_{i}+\boldsymbol{k}_{T}$ が成立し，屈折率の波 長分散特性のために励起光の光軸からの散乱角に応じて アイドラー光およびテラヘルツ光の波長が定まる. 光強 度が〜 $100 \mathrm{MW} / \mathrm{cm}^{2}$ 程度以上のナノ秒パルスレーザーを 用いてシングルパスで $\mathrm{LiNbO}_{3}$ 結晶 $\left(\mathrm{A}_{1}\right.$ 対称モードの最低 準位: $\left.\omega_{T O}=250 \mathrm{~cm}^{-1}=7.5 \mathrm{THz}\right)$ を励起すると, 帯域が $1 \mathrm{THz}$ 超えるアイドラー光およびテラヘルツ光の発生 が観測される。本稿では，このシングルパス励起の広帯 域なテラヘルッ光の発生をテラヘルッ光パラメトリック 発生と呼ぶ.

テラヘルッ光パラメトリック発生の利得幅は, パラメ トリック利得と非線形光学結晶によるテラヘルツ光の吸 収によって決まり，共鳴周波数から十分離れた低周波領 域において，平面波近似の下でノンコリニア位相整合条 件 $\left(\boldsymbol{k}_{p}=\boldsymbol{k}_{i}+\boldsymbol{k}_{T}\right)$ を考慮して求めると, パラメトリック利 得 $g_{T}$ は,

$$
g_{T}=\frac{\alpha_{T}}{2}\left\{\sqrt{1+16 \cos \phi\left(\frac{g_{0}}{\alpha_{T}}\right)^{2}-1}\right\}
$$

と表される。ここで, $\phi$ は励起光とテラヘルツ光の間の 位相整合角, $g_{0}$ は低ロス限界でのパラメトリック利得, $\alpha_{T}$ はテラヘルツ光の吸収係数を表し,

$$
g_{0}=\sqrt{\frac{\pi \omega_{p} \omega_{i} I_{p}}{2 c^{3} n_{T} n_{i} n_{p}}} \chi_{p} \propto \sqrt{\omega_{i} \omega_{T} I_{p}}
$$



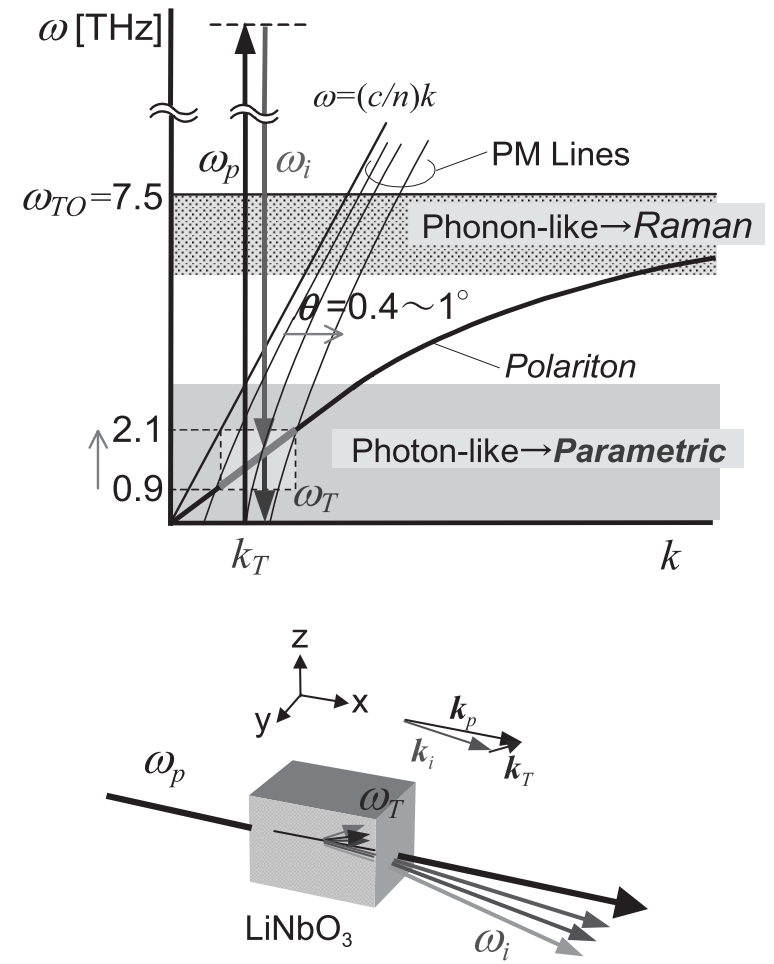

Fig. 1 The dispersion relation of the polariton and the noncollinear phase matching condition in $\mathrm{LiNbO}_{3}$.

$$
\begin{aligned}
& \chi_{P}=d_{E}+\frac{S_{0} \omega_{0}{ }^{2}}{\omega_{0}{ }^{2}-\omega^{2}} d_{Q} \\
& \alpha_{T}=\frac{2 \omega}{c}\left|\operatorname{Im}\left(\sqrt{\varepsilon_{T}}\right)\right|
\end{aligned}
$$

である ${ }^{10,17)}$ ，ただし， $I_{p}$ は励起光強度， $c$ は真空中の光 速, $n_{T}, n_{i}, n_{p}$ はそれぞれ, テラヘルツ光, アイドラー光, 励起光の屈折率, $S_{0}$ は振動子強度, $\omega_{0}$ は $\mathrm{A}_{1}$ モードの共鳴 周波数, $d_{E}, d_{Q}$ はそれぞれ電子分極, イオン分極に起因 した 2 次と 3 次の非線形光学過程, $\varepsilon_{T}$ は誘電率を表す.

東北大の四方らは, 一致溶融組成 $\mathrm{LiNbO}_{3}$ 結晶を $\mathrm{X}(\mathrm{ZZ}) \mathrm{Y}$ 配置で測定したラマンスペクトルの解析によ り, $\mathrm{A}_{1}$ モードの固有周波数および線幅(減衰定数)を決 定し, 周波数依存性を示した ${ }^{17)}$. Fig. 2に, これらの結 果を用いてパラメトリック利得(1) 式を計算した結果を 示す. 非線形結晶を高強度で励起した場合, $3 \mathrm{THz}$ 以上 の領域に及ぶ周波数領域にわたって数 $\mathrm{cm}^{-1}$ 以上の高い利 得を有することがわかる。上記の低周波モードは, 吸収 係数 $\alpha_{T}$ に付加的なピークとして寄与するため, パラメト リック利得にディップ(2.7 THz付近)となって現れる.

\section{3. 実験装置}

Fig. 3に, 実験装置の概略図を示す。実験装置は, 励 起光源(マイクロチップNd:YAGレーザー), 波長板, レ ンズ, ミラー, 非線形光学結晶 $\left(\mathrm{MgO}: \mathrm{LiNbO}_{3}\right)$, 注入光 源 (外部共振器型半導体レーザー), アイソレーター, テ ラヘルツ光用レンズ, テラヘルッ光検出器 (4 K シリコン ボロメーター, SBD)によって構成される，発生したテ

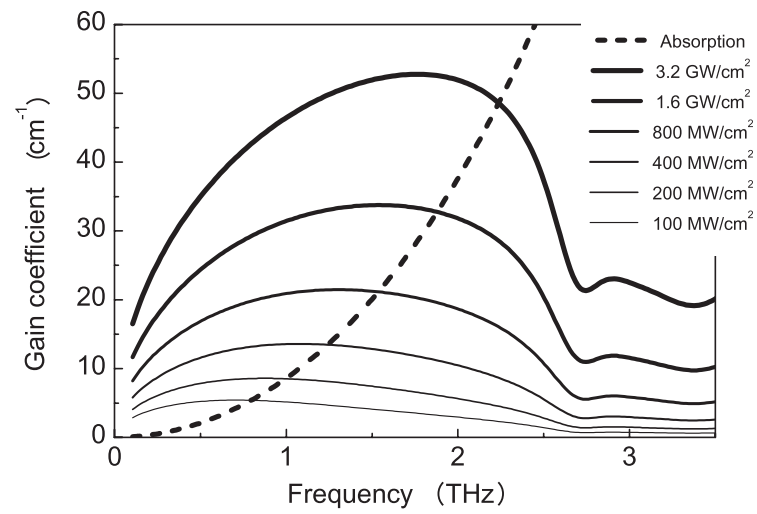

Fig. 2 Calculated gain coefficient for terahertz wave generation using $\mathrm{MgO}: \mathrm{LiNbO}_{3}$ crystal pumped at 1064 nm.

ラヘルツ光を検出するための光学系を除くと, テラヘル ツ光パラメトリック発生に必要な部分は, 励起光源に小 型の単一縦モードLD励起受動Qスイッチ動作マイクロ チップNd:YAGレーザー ${ }^{18,19)}$ を使用したことで, $15 \times$ $25 \mathrm{~cm}^{2}$ 程度と非常に小型である。このレーザーは，発振 線幅 $0.009 \mathrm{~nm}$ 以下, 出力 $1.3 \mathrm{MW}(0.7 \mathrm{~mJ} / \mathrm{pulse}$, パルス幅 $0.5 \mathrm{~ns}$ ), 繰り返し100 Hzである。また, 過飽和吸収体 $\left(\mathrm{Cr}^{4+}: \mathrm{YAG}\right)$ による受動Qスイッチ動作のため電気ノイズ が少なく，出力摇らぎも $\pm 2 \%$ 小さい.

両端面に励起光 $(1,064 \mathrm{~nm})$ に対する無反射膜を施した 2本のMgO: $\mathrm{LiNbO}_{3}$ 結晶 $\left(\right.$ 各 $\left.4 \times 5 \times 65 \mathrm{~mm}^{3}\right)$ を間隔 $100 \mu \mathrm{m}$ 以下になるように縦列配置し，レンズによって並行光と なった励起光 $(\phi 0.3 \mathrm{~mm})$ を入射した. 励起光は結晶中 を，ノンコリニア位相整合条件を満たす方向にアイド ラー光およびテラヘルツ光を発生させながら通過する. このとき, 注入光 (連続波, 出力: $100 \mathrm{~mW}$, 波長 : 1,065 1,080 nm) を，1本目の結晶入り口において， ンコリニア位相整合条件を満たすように波長と入射角度 を選択し，注入する。

$\mathrm{MgO}: \mathrm{LiNbO}_{3}$ 結晶は数 $\mathrm{THz}$ 帯に大きな吸収係数 $(10$ $\left.100 \mathrm{~cm}^{-1} @ 1 \sim 3 \mathrm{THz}\right)$ を持つため, 効率よくテラヘルツ光 を取り出すためには, 励起光を結晶の取り出し面近くを 励起しなければならない. 本研究では, 出力テラヘルッ 光が最大になるように調整した。発生したテラヘルッ光 は，2つ目の結晶のy面に圧着したシリコン製プリズムア レイによって結晶外に取り出され, レンズ系で集光後, $4 \mathrm{~K}$ シリコンボロメーターによって検出される。検出器 が飽和する場合は薄膜減衰器を使用した。 なお，テラへ

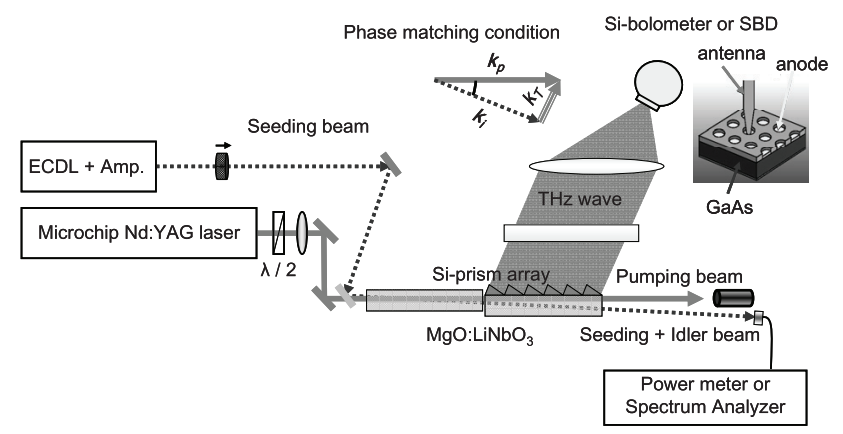

Fig. 3 Experimental setup. 


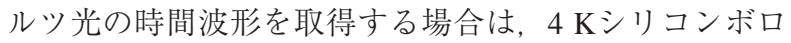
メーターの代わりにショットキーバリアーダイオード (SBD)を使用した。アイドラー光の強度, スペクトルは それぞれ，パワーメーター，光スペクトラムアナライ ザーによって検出した

\section{4. 結果と考察}

Fig. 4に, アイドラー光出力の, 励起光強度依存性を 示す. 光注入を行わない場合, 励起光強度が上昇し, $400 \mu \mathrm{J} / \mathrm{pulse}$ (尖頭值 $1.4 \mathrm{GW} / \mathrm{cm}^{2}$ ) 付近に達するとアイド ラー光が観測され始める。 その後，励起光エネルギーの 増加に伴ってアイドラー光出力は単調に増加し, 最高出 力は, 励起光強度が750 $\mu \mathrm{J} / \mathrm{pulse}\left(2.9 \mathrm{GW} / \mathrm{cm}^{2}\right)$ のとき, アイドラー光は $110 \mu \mathrm{J} / \mathrm{pulse}$ であった. 従来の励起光源 である単一縦モード動作のフラッシュランプ励起Q イッチNd:YAGレーザー(パルス幅15 ns)を利用した場合と 比較すると, アイドラー光の発生しきい值が41 mJ/pulse ${ }^{12}$ から $400 \mu \mathrm{J} / \mathrm{pulse}$ 以下と約 $1 / 100$ に, 非線形光学結晶の損 傷しきい值は $450 \mathrm{MW} / \mathrm{cm}^{2}{ }^{12)}$ から $2.9 \mathrm{GW} / \mathrm{cm}^{2}$ 以上と約6倍 に改善された。これらはいずれも，励起光のパルス幅が 短くエネルギーが小さいため，熱的な損傷を抑えられた ことにより実現されたと考えられる。また，飽和や損傷 の傾向は見られないことから，さらに高強度励起するこ とによってアイドラー光の出力向上が見达まれる.

Fig. 5に, 励起光エネルギーが750 $\mu \mathrm{J} /$ pulseのときのア イドラー光スペクトルを示す．アイドラー光は1,069.1 $1,074.9 \mathrm{~nm}$ の領域で観測された。これは，テラヘルッ光 周波数1.45 2.97 THzに相当する. 励起光の尖頭值が高 いため, 従来型と比較して, アイドラー光強度の最大值が $1,070 \mathrm{~nm}$ 付近 (1.5 THz相当) ${ }^{12)}$ から $1,072 \mathrm{~nm}$ 付近 $(2.1 \mathrm{THz}$ 相当)へと長波長側に移動している.

Fig. 6に, 出力テラヘルッ光時間波形を示す. 注入光 を行う場合と行わない場合を重ねて示してある。励起光 エネルギーはいずれの場合も $550 \mu \mathrm{J} / \mathrm{pulse}$ である。注入 光がない場合 (下方), 出力約 $1 \mathrm{~mW}$ (尖頭值), 周波数 1.5 〜 $2.7 \mathrm{THz}$ の広帯域なテラヘルツ光が観測された. 光注 入 $(200 \mathrm{~mW})$ を行った場合, 出力約 $20 \mathrm{~mW}$ (尖頭值), 周 波数 $1.6 \mathrm{THz}$ のテラヘルツ光が観測された.これは, 光

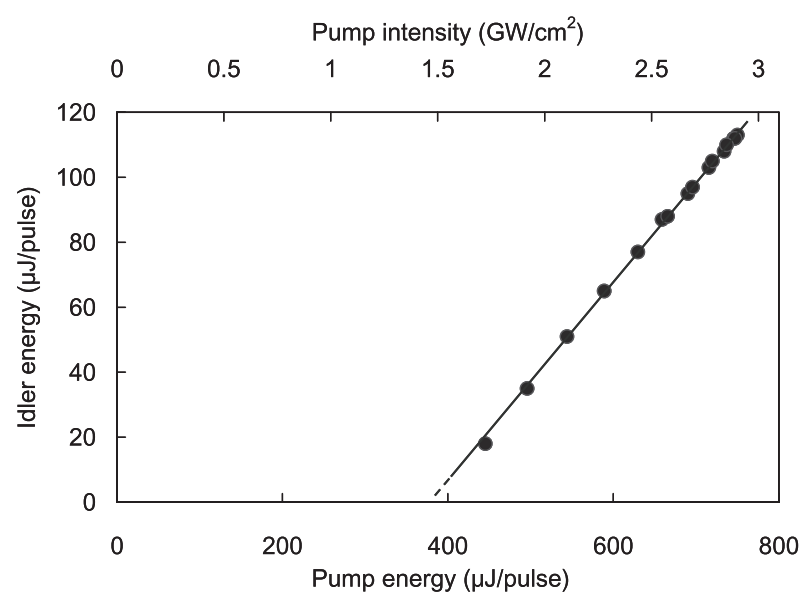

Fig. 4 Pumping energy dependence of Idler wave.

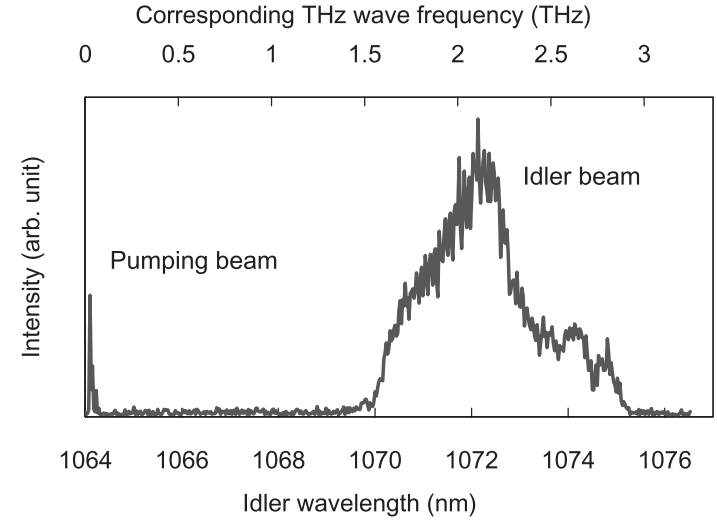

Fig. 5 Idler wave spectrum.

注入を行わない場合と比較して20倍程度の出力増強であ る.

Fig. 7に，光注入を行った場合の，メタルメッシュエ タロンによる出力テラヘルツ光の波長および発生線幅計 測の結果を示す。メタルメッシュエタロンの透過テラヘ ルツ光強度変化より, 波長約 $140 \mu \mathrm{m}$ (周 波数約 $2.14 \mathrm{THz})$ ，発生線幅 $10 \mathrm{GHz}$ 以下と見積もることができ る。これは, 光注入がない場合と比較して，100倍以上 の発生テラヘルツ光線幅の狭窄化 $(1 \mathrm{THz}$ 以上 $\rightarrow 10 \mathrm{GHz}$ 以下)である。

Fig. 8に, テラヘルツ光出力の周波数依存性を示す. 注入光の波長と励起光とのなす角を，ノンコリニア位相 整合条件を満たすように変化させることによって，0.9 ～3 THzの範囲でテラヘルツ光の波長が変化する様子を 観測した。最大のテラヘルツ光出力は, 励起光エネル

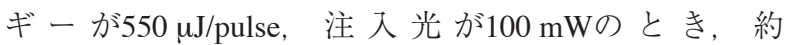
$100 \mathrm{~mW}$ (尖頭值)，1.85 THz付近であった。これは，ア イドラー光スペクトルと同様に, 過去の報告 $(1.4 \mathrm{THz}$ 付 近 $\left.{ }^{12)}\right)$ と比較して高周波側に移動しており，これは主に， Fig. 2に示した，高強度励起による利得曲線の広帯域化 およびピーク周波数の移動を反映していると考えられ る. $1,073 \mathrm{~nm}$ 付近に見られるテラヘルツ光出力の落ち込 みは，損傷しきい值向上のためにドープした $\mathrm{MgO} に$ 起 因している。 $\mathrm{MgO}$ は $\mathrm{LiNbO}_{3}$ の結晶に格子欠陥として作 用するため, 利得曲線に特定周波数における利得の落ち 込みが現れる ${ }^{17)}$ 。これは，結晶の損傷しきい值の制約に より，計算により予想されていながら観測できなかった スペクトル形である。

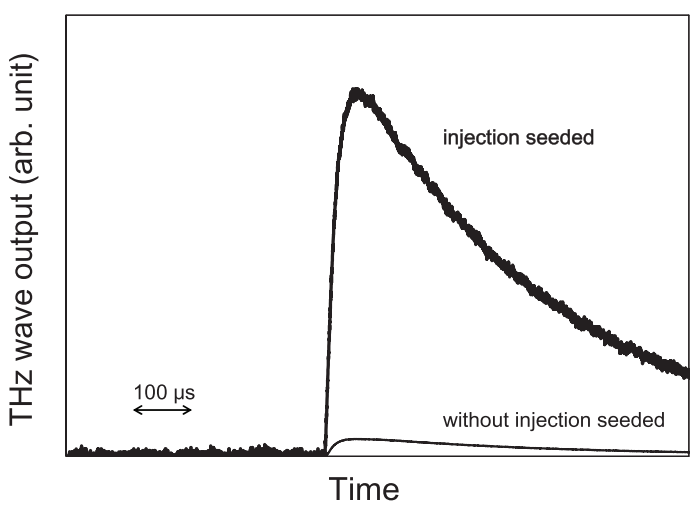

Fig. 6 Time dependent signal of terahertz-wave. 


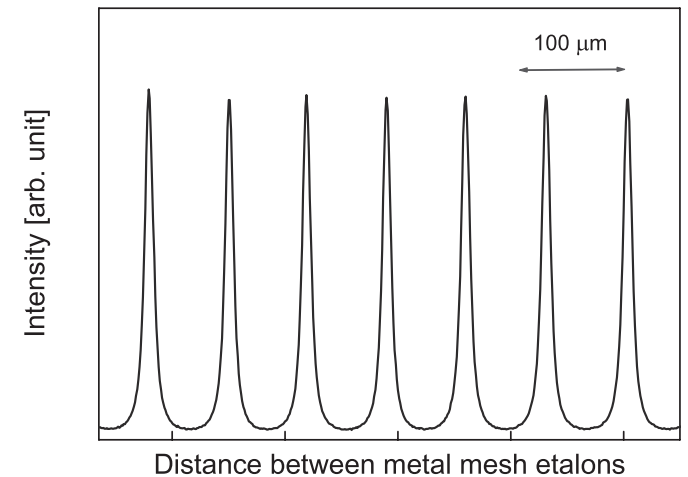

Fig. 7 An example of wavelength and linewidth measurement by scanning Fabry-Perot etalon consisting if two metal mesh plate.

Fig. 9に, 検出器としてSBDを用いた場合のテラヘル ツ光出力の時間波形を示す. 受動Qスイッチ動作の励起 光源を用いたため, 従来の励起光源使用時に比べてQ久 イッチによる電気雑音の少ない， S/N比の良い信号を観 測した。

\section{5. まとめ}

小型短パルス, 単一縦モード発振, 受動Qスイッチ動 作のマイクロチップNd:YAGレーザーを励起光源として 用いて光源全体の小型化を図ると共に，熱損傷閾值を緩 和し，高強度励起による広带域波長可変，高尖頭值テラ ヘルッ光源を実現した. $15 \times 25 \mathrm{~cm}^{2}$ 程度の小型テラヘル ッ光パラメトリック光源から, 波長可変範囲0.9 $3.0 \mathrm{THz}$, 発振線幅 $10 \mathrm{GHz}$ 以下, 最高出力 $100 \mathrm{~mW}$ (尖頭 值)のテラヘルッ光を発生・観測した. この小型励起光 源, 非線形光学結晶をべースとするコンパクトなテラへ ルツ波光源は, 常温動作で操作も簡便であり, テラヘル ツ領域に扔ける応用研究に打いて有力なツールとなるこ とが期待される。

\section{謝 辞}

本研究を進めるにあたりご協力いただいた，理研の 南出泰亜サブチームリーダー, 伊藤弘昌チームリー ダー, 平山 秀樹チームリーダー, 緑川 克美主任研究員, 庄子長一氏，東北大の四方潤一准教授，田久長一氏に 深く感謝いたします。また, 本研究の一部は, 第24回 (平成20年度) (財)村田学術振興財団研究助成によって行 われました。感謝いたします。

\section{参考文献}

1) 斗内 政吉：テラヘルツ技術(オーム社, (2006)).

2) P. R. Smith, D. H. Auston, and M. C. Nuss: IEEE J. Quantum Electron. 24 (1998) 255.

3) P. Y. Han and X.-C. Zhang: Appl. Phys. Lett. 73 (1998) 3049.

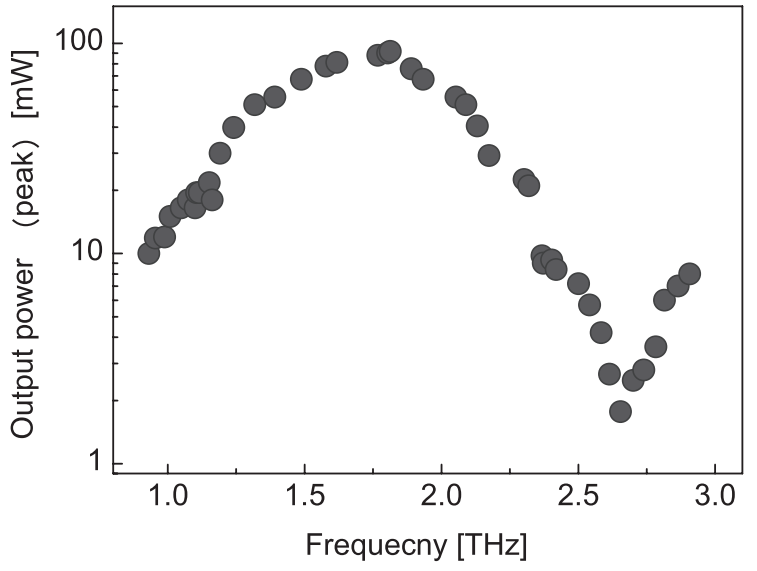

Fig. 8 Tunability of an is-TPG.

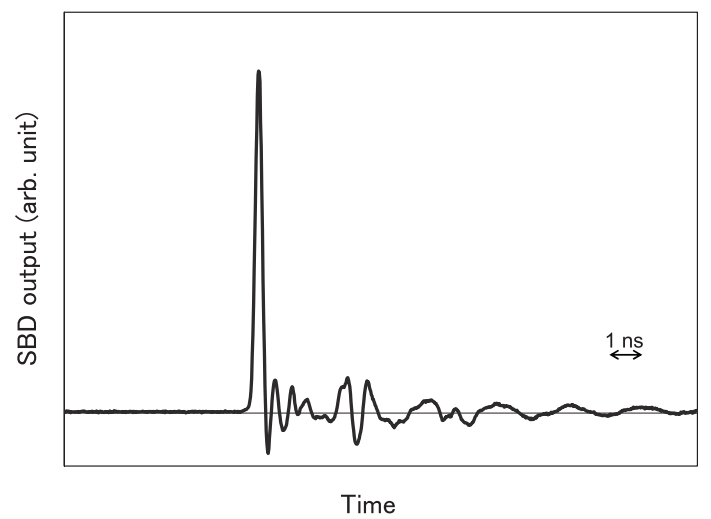

Fig. 9 Temporal waveform of terahertz wave.

4) D. M. Mittleman, R. H. Jacobsen, and M. C. Nuss: IEEE J. Sel. Top. Quantum Electron. 2 (1996) 679.

5) R. A. Cheville, R. W. McGowan, and D. Grischkowsky: Phys. Rev. Lett. 80 (1998) 269.

6) J. Allen: Free Electron Lasers and Other Advanced Sources of Light (National Academy Press, Washington, DC, (1994)) p.24.

7) S. Komiyama: Phys. Rev. Lett. 48 (1982) 271.

8) E. B. Brown, K. A. McIntosh, K. B. Nichols, and C. L. Dennis: Appl. Phys. Lett. 66 (1995) 285.

9) J. Faist, F. Capasso, D. L. Sivco, C. Sirtori, A. L. Hutchinson, and A. Y. Cho: Science 264 (1994) 553.

10) S. S. Sussman: Microwave Lab. Report No. 1851 (Stanford University (1970)).

11) M. A. Piestrup, R. N. Fleming, and R. H. Pantell: Appl. Phys. Lett. 26 (1975) 418.

12) K. Kawase, J. Shikata, and H. Ito: J. Phys. D: Appl. Phys. 35 (2002) R1.

13) S. Hayashi, H. Minamide, T. Ikari, Y. Ogawa, J. Shiata, H. Ito, C. Otani, and K. Kawase: Appl. Opt. 46 (2007) 117.

14) Y. R. Shen: The Principle of Nonlinear Optics (John Wiley and Sons, New York, (1984)).

15) V. G. Dmitriev, G. G. Gurzadyan, D. N. Nikogosyan eds.: Handbook of Nonlinear Optical Crystals (Springer-Verlag, Berlin, (1997)).

16) E. D. Palik ed.: Handbok of Optical Constants of Solids (Academic Press, San Diego, (1985))

17) J. Shikata, K. Kawase, K. Karino, T. Taniuchi, and H. Ito: IEEE Trans. Microwave Theory Tech. 48 (2000) 653.

18) N. Pavel, J. Saikawa, S. Kurimura, and T. Taira: Jpn. J. Appl. Phys. 40 (2001) 1253

19) H. Sakai, H. Kan, and T. Taira: Opt. Express 16 (2008) 19891. 